\title{
Nilai Moral sebagai Prediktor Orientasi Politik pada Anggota Organisasi Keagamaan
}

\author{
Irfan Fahmi ${ }^{1}$, Bagus Takwin ${ }^{2}$, Roby Muhamad ${ }^{2}$ \\ ${ }^{1}$ Fakultas Psikologi, UIN Sunan Gunung Djati Bandung, Indonesia \\ ${ }^{2}$ Fakultas Psikologi, Universitas Indonesia, Indonesia \\ e-mail: irfan.fahmi@uinsgd.ac.id
}

\begin{abstract}
This study aims to examine the relationship of moral values formed in five moral values, harm/care, fairness/ reciprocity, ingroup/loyalty, authority/respect and purity/sanctity with the political orientation of the various Islamic organizations in Indonesia. Research carried out by the quantitative method with the correlational approach. Participants in this study were 531 Muslims who affiliated the Nahdlatul Ulama (NU), Muhammadiyah, Persis, Mathlaul Anwar, PUI, LDII, and Hizb ut-Tahrir Indonesia (HTI). The results show that Muslim organizations in Indonesia showed different patterns in the moral values that associated with the political orientation of Islam. Based on this research Nahdlatul Ulama (NU), Muhammadiyah, Mathlaul Anwar, PUI, and LDII including Islamic groups with a political orientation inclusive while Persis and Hizb ut-Tahrir Indonesia (HTI), including the Islamic group with exclusive political orientation.
\end{abstract}

Keywords: moral values, political orientation, islamic organization, inclusive-exclusive

\begin{abstract}
Abstrak
Penelitian ini bertujuan untuk melihat hubungan nilai moral yang terbentuk dalam lima nilai moral, yakni nilai kepedulian, keadilan, kesetiaan, hormat pada otoritas dan nilai kesucian dengan orientasi politik pada berbagai ormas Islam di Indonesia. Penelitian dilakukan dengan metode kuantitatif dengan pendekatan korelasional. Partisipan pada penelitian ini adalah 531 muslim yang terafiliasi pada Nahdlatul Ulama (NU), Muhammadiyah, Persis, Mathlaul Anwar, Persatuan Umat Islam (PUI), Lembaga Dakwah Islam Indonesia (LDII), dan Hizbut Tahrir Indonesia (HTI). Hasil yang diperoleh dalam penelitian ini adalah setiap ormas Islam di Indonesia memperlihatkan pola yang berbeda dalam nilai moral yang memprediksi orientasi politik Islam. Berdasarkan penelitian ini Nahdlatul Ulama (NU), Muhammadiyah, Mathlaul Anwar, Persatuan Umat Islam (PUI), dan Lembaga Dakwah Islam Indonesia (LDII) termasuk kelompok Islam dengan orientasi politik inklusif sementara Persis dan Hizbut Tahrir Indonesia (HTI) termasuk pada kelompok Islam dengan orientasi politik ekslusif.
\end{abstract}

Kata kunci: nilai moral, orientasi politik, ormas Islam, inklusif-ekslusif

\section{Pendahuluan}

Dalam kehidupan politik Indonesia dewasa ini, isu perbedaan agama, kelompok minoritas dan intoleransi makin berkembang. Masyarakat pun terpecah ke dalam pendapat dan kelompok yang berbeda mengenai wacana politik yang muncul. Perbedaan pemahaman ini kemudian berujung pada perbedaan ideologi atau orientasi politik yang dianut, bahkan pertarungan politik. Pertarungan politik pada dasarnya merupakan pertarungan ideologi di antara kelompokkelompok yang terlibat di dalamnya (Ali, 2012).

Sejak lama para ahli psikologi tertarik mengenai faktor psikologis yang mendasari seseorang melaksanakan aktivitas politik (Winter, 2003), khususnya mengenai orientasi politik. Selama ini orientasi politik senantiasa mengacu pada dua kontinum besar yakni, liberal versus konservatif atau dimensi kiri versus kanan (van Prooijen \& Krouwel, 2019). 
Identifikasi politik pada liberalkonservatif efektif digunakan hampir 200 tahun untuk membedakan sikap politik. Adapun makna yang dimaksud ideologi liberal-konservatif mengalami perubahan dari waktu ke waktu. Jost dkk. (2003) mengidentifikasi dua dimensi yang relatif stabil, dimensi inti yang dapat menangkap makna penting dari perbedaan antara ideologi liberal dan konservatif yakni sikap terhadap ketidakadilan dan sikap terhadap perubahan sosial dan tradisi. Secara tegas mereka berpendapat bahwa inti dari konservatisme terdiri dari resistensi terhadap perubahan dan menerima hirarki serta ketidaksetaraan di antara kelompokkelompok atau individu. Hanya saja mereka tidak pernah menjelaskan bagaimana resistensi terhadap perubahan dapat dipertahankan sebagai inti dari konservatisme politik ketika hal tersebut dilakukan pada individu atau kelompok yang disinyalir sebagai konservatif (Greenberg \& Jonas, 2003).

Pembagian kategorisasi liberalkonservatif ini banyak digunakan di berbagai negara terutama di Amerika Serikat. Meskipun demikian, sebenarnya banyak orang yang tidak bisa membedakan secara tepat di antara kedua kategori tersebut. Kategori liberal atau konservatif di Amerika Serikat nyatanya memiliki makna yang berbeda bila dibandingkan dengan negara-negara di Eropa, khususnya Eropa bagian Timur (Greenberg \& Jonas, 2003). Berbeda dengan negara seperti Polandia, konservatif senantisa dikaitkan dengan "status quo" yakni komunisme.

Berbagai pendekatan dan teori terutama yang menggunakan pendekatan kognitif dan motivasional, seperti Value Balance Model, A Dual-Process Motivational Model (Duckitt \& Sibley, 2010; Claessens dkk., 2019), Motivated Social Cognition Model (Jost dkk., 2003) belum memberikan penjelasan yang komprehensif berkaitan dengan orientasi politik. Selain itu juga karena pemaknaan kategori liberal-konservatif yang tidak ajeg sehingga memberikan simpulan yang berbeda terkait suatu masyarakat atau kelompok tertentu. Penelitian yang dilakukan Kossowska dan Van Hiel (2003) menunjukkan bahwa orientasi politik akan berbeda berdasarkan konsep negara, dalam hal ini dominasi masyarakat yang ada pada negara tersebut. Pada negara Polandia yang dimaksud konservatif; dianggap tradisionalis dan status quo adalah komunisme. Sementara di Flanders yang dimaksudkan konservatif adalah kapitalisme.

Beragamnya pemaknaan mengenai orientasi politik liberal dan konservatif membuat banyak orang tidak bisa membedakan secara tepat di antara keduanya, sehingga tidak menggunakan kategorisasi tersebut dalam mengevaluasi kandidat dan partainya (Feldman, 2003). Ditemukan pula adanya berbagai variasi mengenai orientasi atau ideologi politik dari individu yang bergerak di antara dua kontinum tersebut.

Perkembangan terakhir, upaya memahami orientasi politik mulai bergeser pada kajian non kognitif-emosional yakni melalui pendekatan moral. Moral foundation theory (Haidt dkk., 2009) adalah pendekatan moral yang bersifat emosional (moral intuition). Pendekatan ini memiliki kelebihan karena selain melihat pentingnya stabilitas struktur fondasi moral dan perbedaan individual, juga melihat meaning matters (Medin dkk., 2006) yakni narasi dan pemaknaan budaya terkait isu peraturan dan konteks sosial sebagai hal yang juga penting dalam proses identifikasi diri secara ideologis. Teori fondasi moral juga mengakui pentingnya pengaruh dari budaya dalam moral judgment seseorang. Ada 5 prinsip utama dalam moral foundation, yang dibagi pada dua fondasi utama yakni individualizing foundation dan binding foundation. Individualizing foundation adalah sumber moral yang merupakan bawaan individu, terdiri dari prinsip harm/care (kepedulian) dan prinsip fairness/reciprocity (keadilan). Sedangkan 
binding foundation adalah sumber moral yang berasal dari tradisi budaya/masyarakat terdiri dari prinsip ingroup/loyalty (kesetiaan), prinsip authority/respect (hormat pada otoritas), dan prinsip purity/sanction (kemurnian).

\section{Orientasi Politik Konteks Indonesia: Inklusif-Ekslusif}

Perdebatan pada politik Islam bukan pada polarisasi liberal-konservatif melainkan pada perbedaan paradigma menyikapi hubungan Islam dan demokrasi dalam konteks politik modern. Hal ini terjadi tatkala negara-negara Muslim, termasuk Indonesia, harus merancang konstitusi modern untuk negaranya setelah mengalami kemerdekaan.

Ada yang berbeda dan bahkan ada yang bertentangan mengenai Islam dan politik ini. Alquran sendiri tidak memberikan suatu pola teori kenegaraan yang tergambar secara jelas dan tegas. Namun pesan utama Alquran adalah agar nilai-nilai dan perintah etiknya dilaksanakan dalam kaitan dengan urusan sosio-politik umat manusia (Maarif, 1987). Dalam politik Islam, hal mendasar tentang ketatanegaraan yakni pelaksanaan syariat Islam dalam konstitusi negara. Kewajiban penerapan syariat Islam ini memiliki hubungan erat dengan gagasan negara Islam (Islamic state) yang merupakan respon terhadap gagasan negara kebangsaan (nation-state) yang berkembang dalam dunia modern. Keduanya dapat dibedakan dari sejauhmana keterlibatan agama yakni syariat Islam dalam sistem ketatanegaraan. Persoalan yang muncul kemudian sejauhmana ajaran Islam menerima konsep negara kebangsaan tersebut.

Sebagian muslim meyakini bahwa pada dasarnya Islam tidak dapat memisahkan antara agama dan politik. Watak holistik Islam ini berarti bahwa Islam seharusnya menyediakan "landasan sikap moral yang benar bagi (hampir seluruh) tindakan manusia," termasuk dalam urusan politik (Effendy, 2011). Dalam penerapannya muncul persoalan apakah harus dibangun dalam pola legal dan formal atau substansial. Hal ini kemudian menjadi akar permasalahan yang rumit dalam konteks politik Islam.

Dalam konteks sejarah Indonesia, sejak akhir kolonial Belanda sekitar tahun 1920an bibit pertentangan ideologi sudah mulai ada, yakni antara golongan Islamis (Islam politik) dan golongan nasionalis. Permasalahannya dimulai dari masalah nasionalisme yang melebar ke masalah model negara Indonesia yang hendak dicita-citakan. Golongan Islamis lebih mengedepankan adanya penyatuan agama (Islam) dengan negara. Sementara golongan nasionalis menolaknya.

Fenomena pertarungan ideologis ini terus berlanjut hingga kini dan bahkan semakin meruncing. Adanya jaminan kebebasan berpikir dan berekspresi semakin membuat nyata pertarungan tersebut. Bahkan dalam kelompok keagamaan yang telah mapan seperti Muhammadiyah misalnya, sudah tersusupi ide gerakan Islam Baru tersebut. Hal ini terlihat dari munculnya pertarungan antara "Islam Murni" versus "Islam Progresif" dalam tubuh Muhammadiyah (Boy, 2009). Hal ini dipertegas oleh Van Bruinessen (2014) yang berpendapat bahwa situasi dan kondisi masyarakat Indonesia pasca reformasi menunjukkan semakin kompleknya ideologi politik masyarakat Islam Indonesia. Masyarakat Indonesia yang sebagian besar muslim menunjukkan ideologi politik yang beragam. Ini dapat dilihat dari terpecahnya suara muslim dalam partai-partai. Semenjak Pemilu pertama tahun 1955 digelar, partai Islam belum pernah satupun yang menjadi pemenang (Chumaidy, 2006). Penelitian dari Rehman dan Askari (2010) menunjukkan bahwa Selandia Baru berada di urutan pertama negara yang paling Islami di antara 208 negara. Sementara Indonesia yang mayoritas penduduknya Muslim menempati urutan ke-140. Adapun 
negara-negara yang menjadikan Islam sebagai dasar negara berada di urutan 30-an ke bawah. Hasil penelitian tersebut memberikan gambaran bahwa sesungguhnya bentuk negara Islam belum sepenuhnya berhasil mengaplikasikan ajaran Islam itu sendiri. Namun demikian, pertarungan politik untuk mengusung negara Islam terus berkelanjutan.

Berdasarkan catatan sejarah perjalanan bangsa yang dikemukakan di atas, sesungguhnya perdebatan politik di kalangan umat muslim Indonesia dikerucutkan pada beberapa hal berikut, yakni dasar negara, sistem politik (teokrasi versus demokrasi), simbolisasi agama, dan pemaknaan terhadap teks keagamaan. Perdebatan yang muncul berdasarkan tematema tersebut memberikan peluang terjadinya polarisasi dalam orientasi politik Islam. Umat Islam terpolarisasi pada kutub yang mempersoalkan kewajiban penegakan negara Islam dan kutub lainnya yang tetap menempatkan Pancasila sebagai dasar negara. Berdasarkan sejarah dan kondisi terkini dalam politik Islam di Indonesia pasca Reformasi, peneliti berpendapat sebaiknya perlu ada kategorisasi baru dalam orientasi politik yang sangat khas Indonesia, yakni inklusif-ekslusif.

Peneliti menawarkan istilah orientasi politik Islam inklusif-ekslusif untuk memahami keyakinan dan sikap masyarakat dalam menentukan arah politiknya. Istilah inklusif-ekslusif dipilih dengan pertimbangan bahwa sesungguhnya yang menjadi akar perbedaan dalam umat Islam di Indonesia adalah perbedaan dalam menerima atau menolak ide, pendapat dan gagasan baru di luar konteks keagamaan Islam. Orientasi politik Islam inklusif adalah satu set keyakinan yang menerima segala ide, gagasan dan pemikiran baik yang bersifat global (Barat dan Timur Tengah) maupun tradisi lokal di luar ajaran Islam untuk dijadikan pegangan dalam menentukan keputusan politiknya. Cirinya antara lain pemaknaan secara kontekstual dan substansialis terhadap teks keagamaan; menganggap bahwa dalam Islam tidak memiliki suatu pola baku mengenai sistem politik tertentu yang harus dijalankan umat Islam; lebih menekankan penerapan secara substantif nilai-nilai Islam dalam politik kenegaraan.

Adapun orientasi politik Islam Ekslusif adalah satu set keyakinan yang meyakini kemurnian ajaran Islam yang bersifat sempurna, sakral dan tidak bisa berubah; menolak pengaruh budaya dan tradisi di luar ajaran Islam dalam menentukan keputusan politiknya. Cirinya antara lain pemahaman yang bersifat tekstual, literalis terhadap teks keagamaan; menganggap bahwa Islam adalah agama yang sempurna dan lengkap, termasuk sudah memiliki sistem ketatanegaraan atau politik yang baku; memegang keyakinan adanya integrasi Islam dan negara (al-din wa aldaulah). Oleh karenanya simbolisme politik Islam harus diwujudkan (ideologi negara Islam, partai politik Islam, dll) dalam bentuk yang formalistik, legalistik (Effendy, 2011; Maarif, 1987).

\section{Nilai Moral dan Orientasi Politik Islam}

Nilai-nilai pribadi muncul menjadi pusat ideologi politik. Orang-orang menggunakan nilai-nilai pribadi untuk mengatur dan memprioritaskan kepercayaan dan perasaan mereka mengenai isu-isu politik, untuk membuat dan membenarkan keputusan politik, dan untuk berkomunikasi tentang politik (Feldman, 2003; Schwartz dkk., 2010). Dengan demikian, setiap individu secara nyata memiliki sebuah set keyakinan nilai pribadi dalam upaya merespon dan mempertimbangkan isu-isu politik kekinian yang berkembang.

Banyak peneliti yang melihat nilainilai sebagai prinsip-prinsip yang mendasari orientasi politik (Schwartz dkk., 2010). Jost dkk. (2003) juga menyajikan model kognisi sosial yang mengacu pada kebutuhan psikologis, dinyatakan dalam nilai-nilai, untuk memperhitungkan perbedaan dalam orientasi politik. 
Saat ini ditemukan bahwa nilai-nilai telah menggantikan posisi struktural sosial dan kesetiaan kelompok sebagai penentu penting dari perilaku pemilih (Schwartz, dkk, 2010). Mereka menemukan bahwa nilai pribadi ikut menentukan dalam pemungutan suara di Italia dan Amerika Serikat.

Karakter psikologis berupa nilai khususnya nilai moral menjadi pertimbangan penting dalam menentukan sejauhmana orientasi politik seseorang. Hal ini diperkuat dengan pernyataan bahwa karakter psikologis senantiasa dikaitkan dengan ideologi politik dan dengan adanya pemahaman akan karakteristik psikologis akan menjadi dasar dari perilaku politik individu (Hatemi dkk., 2019). Dalam ilmu politik dan psikologi, nilai moral dan ideologi politik berhubungan erat. Ideologi politik dapat mempengaruhi nilai moral (Voelkel \& Brandt, 2018; Hatemi dkk., 2019).

Sebaliknya, pertimbangan moral juga menjadi prediktor kuat preferensi kebijakan dan pilihan suara, serta identifikasi partisan dan ideologis (Graham, dkk., 2009; Karandikar dkk., 2019). Dalam perspektif Haidt, Graham, dan Joseph (2009) dikemukakan bahwa konservatif dan liberal mengutamakan fondasi yang berbeda dalam fondasi moralnya. Ideologi konservatif mengutamakan hampir semua fondasi moral secara merata sedangkan pada ideologi liberal mereka lebih mengutamakan individualizing foundation dibandingkan binding foundation (Haidt dkk., 2009). Berdasarkan temuan ini, dapat dipahami bahwa nilai moral dapat menjelaskan perbedaan nilai moral yang diutamakan pada kelompok-kelompok yang terlibat dalam pertarungan politik.

Nilai moral ini menjadi hal yang sangat penting dalam konteks masyarakat Indonesia. Peristiwa politik senantiasa dilihat dan dikaitkan dengan moral. Korupsi, nepotisme, money politic, dinasti kekuasaan, isu intoleransi, isu negara Islam, pemilihan kandidat bupati atau presiden dan lain-lain menjadi isu yang hampir selalu dikaitkan dengan moral.

Sejauhmana peranan moral ini apabila diberlakukan pada kelompok muslim Indonesia menjadi hal yang penting untuk ditelaah. Orientasi politik Muslim Indonesia akan dapat diprediksi dari nilai moral yang dipegangnya. Selama ini belum ada model yang secara khusus menjelaskan peranan nilai moral pada orientasi politik untuk masyarakat muslim Indonesia. Pilihan meneliti pada masyarakat muslim dikarenakan kekhasan Islam yang berkembang di Indonesia. Orientasi politik masyarakat Muslim masih sangat dipengaruhi oleh pemahaman akan ajaran Islam, termasuk di dalamnya moralitas.

Teori fondasi moral akan digunakan untuk bisa menjelaskan gejala politik yang terjadi di Indonesia, utamanya dalam orientasi politiknya. Teori fondasi moral mengemukakan bahwa ada lima dasar intuisi moral secara lintas budaya dan muncul dalam evolusi manusia untuk mengatur kehidupan, yakni kepedulian, keadilan, kesetiaan, hormat pada otoritas, dan kemurnian. Kelima nilai tersebut dalam studi ini dipahami sebagai set keyakinan yang satu sama lain berinteraksi dan berperan dalam menentukan orientasi politik individu ataupun kelompok.

Dalam penelitian sebelumnya dengan sampel Amerika Serikat ditemukan bahwa nilai moral kemurnian (purity) menjadi faktor dominan yang menentukan arah ideologi politik pada masyarakat Amerika Serikat (Graham dkk., 2011), begitu pula pada masyarakat Eropa. Berbeda dengan masyarakat Korea Selatan yang menjadikan nilai moral hormat pada otoritas (authority) menjadi faktor paling penting yang menjadi penentu ideologi politik seseorang (Kim dkk., 2012). Perbedaan antara masyarakat Barat (Amerika Serikat) dengan masyarakat Timur (Korea Selatan) terkait dengan pola collectivism dan individualis. Korea Selatan lebih cenderung menganut pola collectivism sedangkan Amerika Serikat lebih 
cenderung individualis (Kim \& Kang, 2013).

Hal menarik lainnya adalah perbedaan pandangan mengenai nilai moral kemurnian pada masyarakat Amerika Serikat dan Korea Selatan. Nilai moral kemurnian pada masyarakat Amerika Serikat lebih tinggi dibandingkan pada masyarakat Korea Selatan. Dengan demikian, peranan agama menjadi sangat berbeda pada kedua negara tersebut. Artinya pemahaman mengenai nilai moral kemurnian pada masyarakat dan negara tertentu akan menjadi sangat berbeda. Hal ini sangat dipengaruhi oleh konteks sejarah, budaya dan masyarakatnya (Kim \& Kang, 2013).

Pada masyarakat religius, prinsip nilai kemurniaan dianggap penting di antara prinsip-prinsip moral lainnya dan menjadi acuan dalam praktek keagamaan dan kehidupan sehari-hari (Haidt dkk., 2009). Hal ini diperkuat Kim dkk. (2012) yang melihat perbedaan konteks budaya dalam moralitas ditentukan perbedaan skor dalam nilai moral kemurnian. Hal ini juga merefleksikan sejauhmana peranan agama dalam percaturan politik negara.

Masyarakat muslim Indonesia sangat menjunjung tinggi nilai agama. Berbagai keputusan moral senantiasa didasarkan pada nilai-nilai dari agama sehingga sulit untuk dibedakan antara nilai moral dengan nilai agama karena sudah menjadi suatu kesatuan utuh (Halstead, 2007). Pada masyarakat muslim Indonesia tentunya peranan nilai kemurnian ini akan menjadi sangat dominan dan bahkan menjadi lebih utama dibandingkan nilai moral lainnya terkait masyarakatnya yang religius. Agama adalah pijakan utama dalam berperilaku sehingga sumber moral bagi muslim Indonesia banyak berasal dari nilai-nilai agama Islam itu sendiri. Moralitas sudah menyatu dalam konsep keagamaan sehingga pemahaman dan pemaknaan nilai keagamaan sesungguhnya mencerminkan realitas moralnya. Saat dihadapkan pada isu dan persoalan politik secara otomatis pertimbangan moralnya senantiasa mengandung unsur nilai-nilai keagamaan yang dipahami dan diyakininya. Hal ini dipertegas bahwa di kalangan muslim, seluruh tindakan politik selalu didasarkan dan diatasnamakan pada doktrin keagamaan.

Dalam studi ini peneliti mencoba untuk memahami orientasi politik dalam konteks politik Islam di Indonesia, sehingga polarisasi orientasi politik dilihat berdasarkan pola inklusifitas-ekslusivitas; tidak berdasarkan polarisasi liberalkonservatif yang selama ini digunakan. Dengan demikian akan secara nyata kita pahami bahwa nilai moral akan sangat menentukan orientasi politik Islam pada masyarakat muslim Indonesia. Dalam hal ini nilai moral kemurnian akan menjadi nilai yang diutamakan dibanding nilai moral lainnya (nilai kepedulian, keadilan, kesetiaan dan hormat pada otoritas) dalam menentukan orientasi politik. Secara khusus dapat dipahami sejauhmana nilai moral (utamanya nilai kemurnian) menentukan dan memprediksi inklusivitasekslusivitas dari orientasi politik Muslim Indonesia.

Beberapa penelitian terdahulu belum dilakukan penelaahan secara empirik dan komprehensif keterkaitan moral dengan orientasi politik dalam suatu konteks kultural dan keagamaan. Pertanyaan penelitian yang diajukan adalah sebagai berikut: Apakah nilai moral mempredikasi orientasi politik inklusif-ekslusif pada Muslim Indonesia? Sejauhmana perbedaan profil nilai moral pada berbagai kelompok organisasi Islam? Sejauhmana perbedaan orientasi politik inklusif-ekslusif pada berbagai kelompok organisasi Islam?

Hipotesis yang akan diuji adalah orientasi politik Islam diprediksi nilai moral kepedulian, keadilan, hormat pada otoritas dan kesetiaan melalui nilai moral kemurnian. 


\section{Metode}

Penelitian ini menggunakan pendekatan korelasional dengan menggunakan model persamaan struktural untuk menjelaskan keterkaitan variabel secara kompleks serta efek langsung maupun tidak langsung dari satu atau beberapa variabel terhadap variabel lainnya, yakni hubungan prediktif atau kausalitas antara variabel eksogen dan variabel endogen (Wijaya, 2009).

Karakteristik subyek dalam penelitian ini adalah sebagai berikut: (1) Individu yang beragama Islam (muslim); (2) pria dan wanita; (3) berusia 18-60 tahun; (4) berafiliasi pada kelompok Islam tertentu. Dalam hal ini ada tujuh ormas yang terlibat yakni Nahdlatul Ulama (NU), Muhammadiyah, Persatuan Islam (Persis), Persatuan Umat Islam (PUI), Mathlaul Anwar, Lembaga Dakwah Islam Indonesia (LDII) dan Hizbut Tahrir Indonesia (HTI). Subyek yang terlibat dalam penelitian ini berjumlah 531 orang yang dijadikan sampel.

Dalam pelaksanaannya peneliti mencoba mencari sejumlah sampel berdasarkan kesediaan partisipan yang menjadi subjek penelitian. Selain meminta kesediaan secara langsung, peneliti juga memperhatikan afiliasi subjek pada kelompok keagamaan Islam sehingga diperoleh sejumlah sampel yang memiliki keterwakilan organisasi keagamaan. Jika dalam prosesnya masih ditemukan keterwakilan yang kurang memadai, peneliti kemudian mencari sejumlah subjek penelitian tersebut.

Tabel 1

Ringkasan Hasil Analisis Faktor Konfirmatorik

\begin{tabular}{lcccc}
\hline \multicolumn{1}{c}{ Variabel } & P-value & RMSEA & GFI & $\begin{array}{c}\text { Kesim- } \\
\text { pulan }\end{array}$ \\
\hline Kepedulian & .604 & .00 & .998 & Fit \\
Keadilan & .0815 & .0327 & .992 & Fit \\
Kesetiaan & .106 & .0299 & .992 & Fit \\
Hormat pada & .102 & .0340 & .994 & Fit \\
Otoritas & & & & \\
Kesucian & .079 & .033 & .992 & Fit \\
Orientasi & .0845 & .0236 & .981 & Fit \\
Politik Islam & & & & \\
\hline
\end{tabular}

Instrumen yang digunakan dalam penelitian ini menggunakan MFQ (Moral Foundation Questionnaire) versi adaptasi yang dilakukan oleh Primaldhi dan Takwin (2016, manuskrip disubmit untuk publikasi). Versi ini dikembangkan dari MFQ yang disusun oleh Graham (2011); Haidt dan Graham (2004). Peneliti fokus pada aspek Moral Relevance dengan total 40 item. Adapun Alat ukur orientasi politik Islam Inklusif-Ekslusif dikonstruksi berdasarkan isu-isu politik berkenaan dengan politik Islam dan konsep mengenai tipologi Islam inklusif-ekslusif (Effendy, 2011; Maarif, 1987) dengan total 12 item.

Uji validitas dan reliabilitas skala dilakukan dengan menggunakan analisis faktor konfirmatorik untuk semua variabel dalam skala yang digunakan dalam penelitian. Ringkasan hasil pengukuran dapat dilihat sebagaimana pada tabel di bawah. Pada tabel tersebut diketahui bahwa semua variabel dalam skala sudah sesuai (fit) dalam mengukur baik skala Nilai Moral maupun Orientasi Politik Islam sehingga bisa dilakukan analisa selanjutnya.

\section{Hasil Penelitian dan Pembahasan}

\section{Prediksi Nilai Moral terhadap Orientasi Politik Islam}

Berdasarkan hasil pengolahan menggunakan analisis faktor konfirmatorik dihasilkan model struktural di bawah ini.

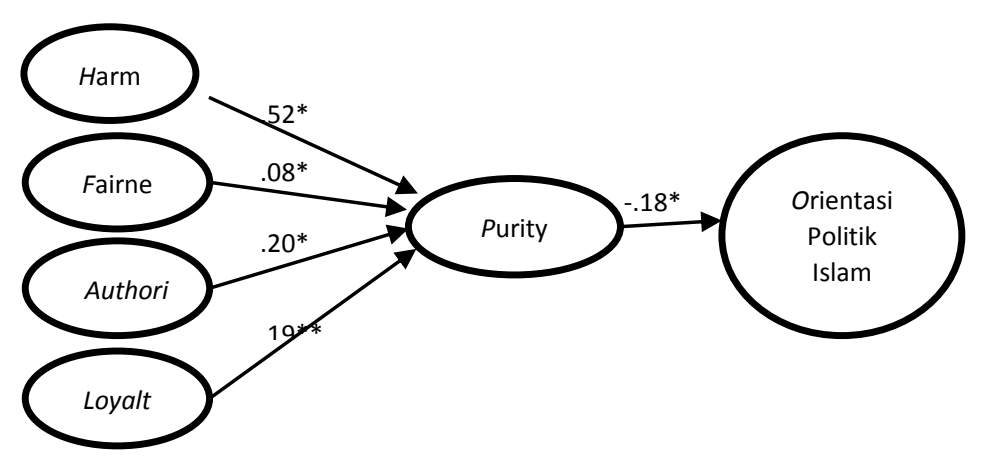

Gambar 1. Model struktural hubungan antara Nilai Moral dengan Orientasi Politik Islam. 
Keterangan: Harm $(H)=$ nilai moral kepedulian; Fairness $(F)=$ nilai moral keadilan; Authority $(A)=$ nilai moral hormat pada otoritas; Loyalty $(L)=$ nilai moral kesetiaan; Purity $(P)=$ nilai moral kemurnian. Signifikansi pada $* p<.00$.

Hasil uji model struktural memperlihatkan pola hubungan yang menunjukkan bahwa variabel kemurnian menjadi mediator bagi variabel kepedulian, keadilan, kesetiaan dan hormat pada otoritas dalam memprediksi variabel orientasi politik Islam. Semua nilai moral baik kepedulian, keadilan, kesetiaan dan hormat pada otoritas dapat memprediksi orientasi politik Islam melalui nilai moral kemurnian. Selanjutnya berkaitan dengan model struktural yang sudah fit dapat dinyatakan sebagai berikut.

Variabel moral kemurnian memprediksi secara langsung orientasi politik Islam (efek langsung sebesar -.18). Kontribusi langsung nilai moral kemurnian terhadap orientasi politik sebesar $3.24 \%$. Variabel moral kepedulian secara signifikan memprediksi orientasi politik Islam melalui nilai moral kemurnian. Kontribusi tidak langsung dari nilai moral kepedulian bersama nilai moral kemurnian sebesar $27.04 \%$.

Variabel moral keadilan secara signifikan memprediksi orientasi politik Islam melalui nilai moral kemurnian. Kontribusi tidak langsung dari nilai moral keadilan bersama nilai moral kemurnian sebesar .64\%. Variabel moral kesetiaan secara signifikan memprediksi orientasi politik Islam melalui nilai moral kemurnian. Kontribusi tidak langsung dari nilai moral kesetiaan bersama nilai moral kemurnian sebesar $4 \%$.

Tabel 2

Hasil Uji Fit Model

\begin{tabular}{lccl}
\hline \multicolumn{1}{c}{ Item } & $\begin{array}{c}\text { Factor } \\
\text { Loading }\end{array}$ & t-value & $\begin{array}{c}\text { Good-ness } \\
\text { of Fit }\end{array}$ \\
\hline Kepedulian & .52 & 12.50 & Model Fit \\
Keadilan & .08 & 2.32 & $\mathrm{P}=.35$ \\
Kesetiaan & .20 & 4.04 & $\mathrm{RMSEA}=.0$ \\
Hormat pada & .19 & 4.75 & 14 \\
otoritas & & & GFI $=1.00$ \\
Kemurnian & -.18 & -4.17 & \\
\hline
\end{tabular}

Variabel moral hormat pada otoritas secara signifikan memprediksi orientasi politik Islam melalui nilai moral kemurnian. Kontribusi tidak langsung dari nilai moral hormat pada otoritas bersama nilai moral kemurnian sebesar $3.61 \%$. Inklusifitas-ekslusifitas orientasi politik Islam ditentukan oleh tinggi rendahnya nilai moral kemurnian.

\section{Prediksi Niai Moral pada Fondasi Moral (Individualizing-Binding) terhadap Orientasi Politik Islam}

Pada bagian ini peneliti berusaha menunjukkan bahwa model pada temuan sebelumnya lebih sesuai dengan konteks Indonesia dibandingkan dengan model yang ditemukan Haidt pada penelitian sebelumnya. Berdasarkan proses analisis faktor konfirmatorik sebagaimana pada gambar 2 ternyata variabel individualizing dan binding bukanlah model yang secara bersama-sama bisa memprediksi variabel orientasi politik Islam. Hal ini karena besarnya korelasi individualizing dan binding yang hampir sama dengan satu (.99) artinya variabel binding dan individualizing adalah serupa dan tidak bisa dibedakan. Dengan demikian, kelima variabel yaitu kepedulian, keadilan, kesetiaan, hormat pada otoritas dan kemurnian tidak bisa dipilah ke dalam dimensi individualizing dan binding.

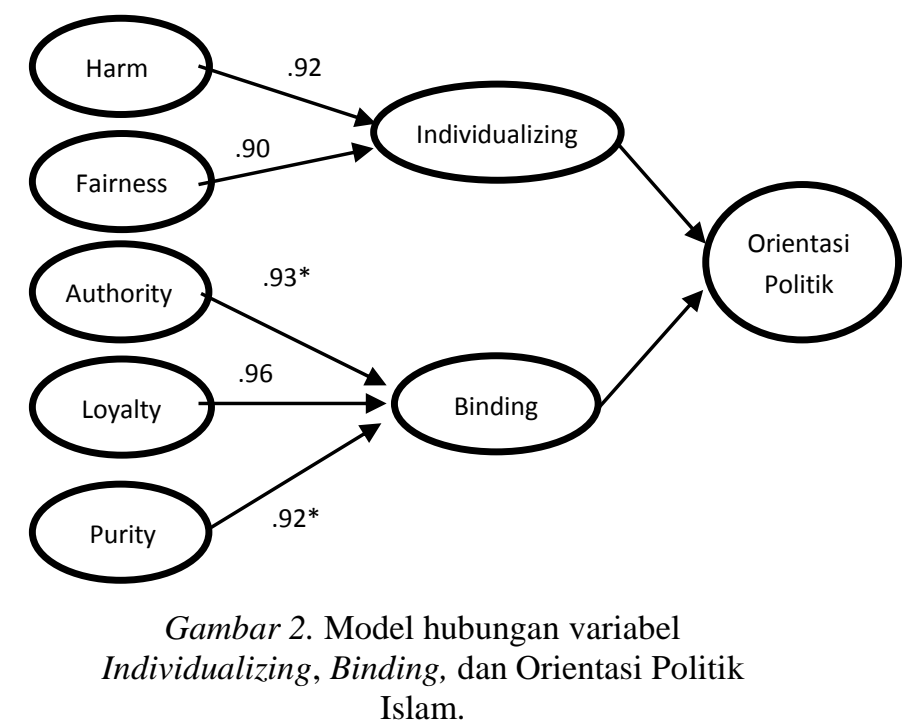


Keterangan: Harm $(H)=$ nilai moral kepedulian; Fairness $(F)=$ nilai moral keadilan; Authority $(A)=$ nilai moral hormat pada otoritas; Loyalty $(L)=$ nilai moral kesetiaan; Purity $(P)=$ nilai moral kemurnian. Signifikansi pada *p $<.05$

Demikian juga bilamana proses regresi variabel individualizing dan binding terhadap orientasi politik Islam dilakukan, skor Beta-nya tidak begitu berbeda, yakni nilai Beta $=-.164$ dan nilai Beta $=-.167$.

Jika kedua variabel, baik variabel individualizing dan binding secara bersama-sama diregresikan dengan menggunakan stepwise regression, terlihat hasil yang berbeda dengan hasil sebelumnya. Ada ketidakonsistenan arah regresi variabel individualizing dari negatif $($ Beta $=-.164)$ menjadi postif $($ Beta $=.151)$ dan hubungannya pun tidak signifikan.

Nilai moral berdasarkan dimensi individualizing dan binding tidak bisa memprediksi orientasi politik Islam. Lebih lanjut peneliti mencoba memaparkan dalam visual mengenai pengaruh nilai moral terhadap orientasi politik Islam sebagaimana gambar 3 .

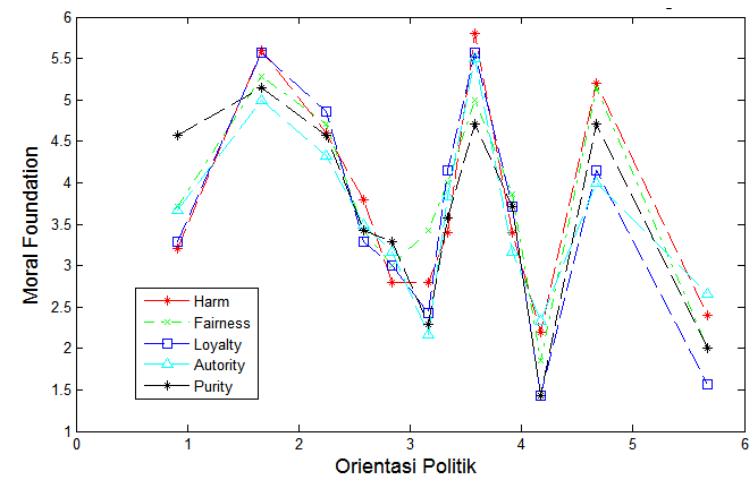

Gambar 3. Hubungan Nilai Moral dengan Orientasi Politik Islam

Gambar 3 menunjukkan bahwa setiap nilai moral berhimpitan sehingga tidak terbedakan dalam kaitannya dengan orientasi politik. Hasil ini berbeda dengan temuan dari Haidt yang bisa membagi kelima nilai moral dalam dimensi individualizing dan binding. Temuan ini membuktikan bahwa dalam konteks Indonesia, nilai moral tidak bisa terbagi dalam fondasi individualizing dan binding. Nilai-nilai moral tersebut menyatu satu sama lain dan menjadi pegangan moral bagi umat Islam Indonesia. Dengan demikian dalam konteks penelitian ini, bahwa dimungkinkan nilai moral secara langsung memprediksi orientasi politik Islam sebagaimana temuan awal di atas.

\section{Perbandingan Pengaruh Nilai Moral terhadap Orientasi Politik Islam Berdasarkan Kelompok Islam}

Hasil pengolahan dan analisis terhadap data dilakukan untuk memaparkan perbandingan nilai moral terhadap orientasi politik Islam berdasarkan kelompok Islam yang berada di Indonesia. Hal ini dimaksudkan untuk menunjukkan bahwa dalam aplikasinya di kelompok Islam terjadi perbedaan dalam penerapan nilai moral itu sendiri. Perbandingan ini dilakukan pada tujuh kelompok Islam yang mewakili kelompok Islam di Indonesia, yaitu Nahdlatul Ulama (NU), Muhammadiyah, Persatuan Islam (Persis), Mathlaul Anwar (MA), Persatuan Umat Islam (PUI), Lembaga Dakwah Islam Indonesia (LDII), dan Hizbut Tahrir Indonesia (HTI). Perbandingan akan diuraikan dalam bentuk grafik untuk memudahkan dalam memahami pola perbedaan tersebut.

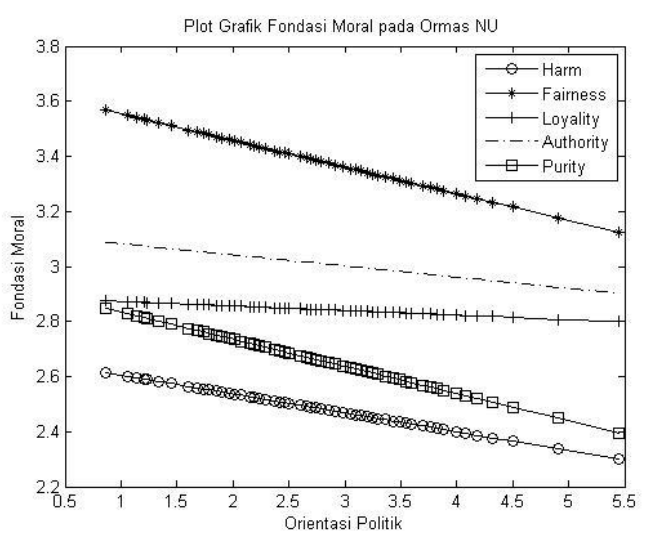

Gambar 1. Hubungan nilai moral dengan orientasi politik islam pada Nahdlatul Ulama (NU) 


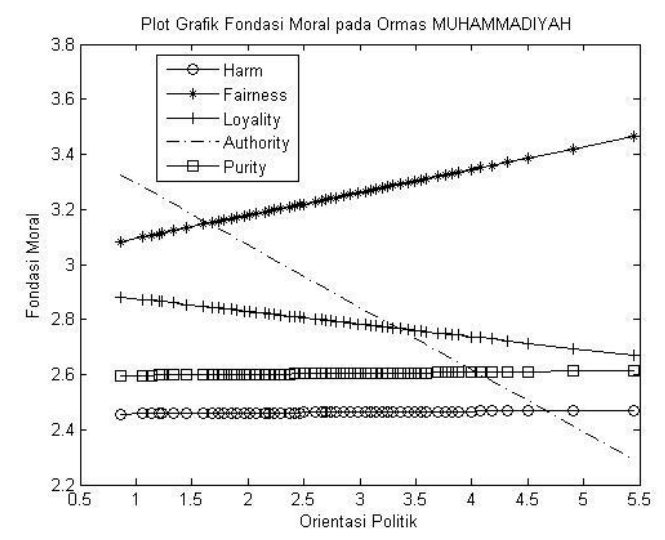

Gambar 2. Hubungan nilai moral dengan orientasi politik islam pada Muhammadiyah

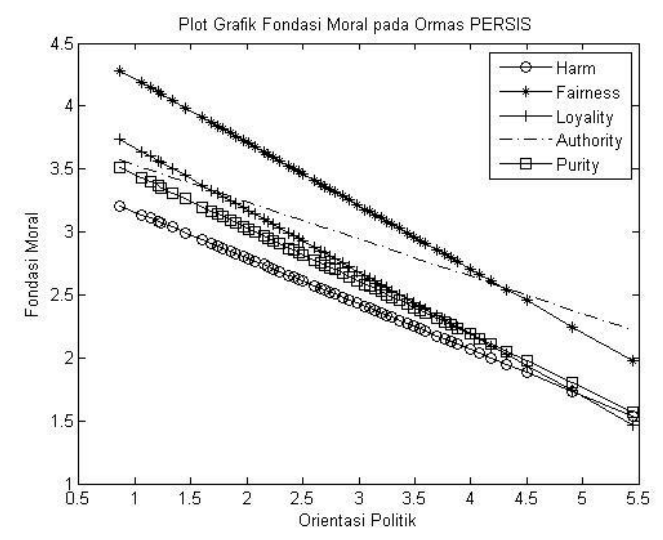

Gambar 3. Hubungan nilai moral dengan orientasi politik islam pada Persatuan Islam (Persis)

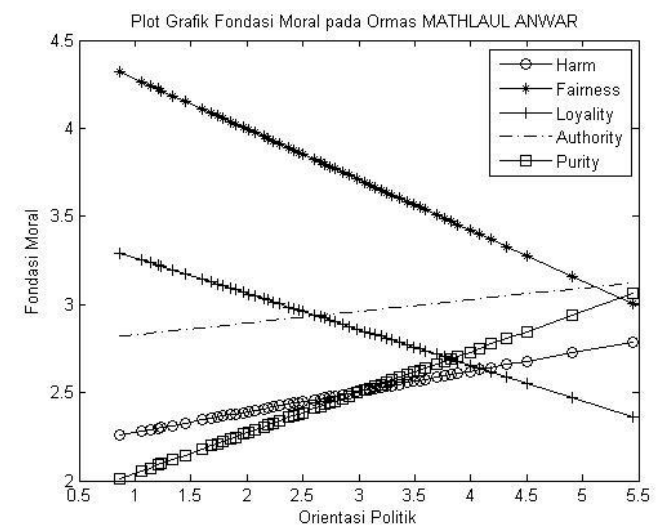

Gambar 4. Hubungan nilai moral dengan orientasi politik islam pada Mathlaul Anwar

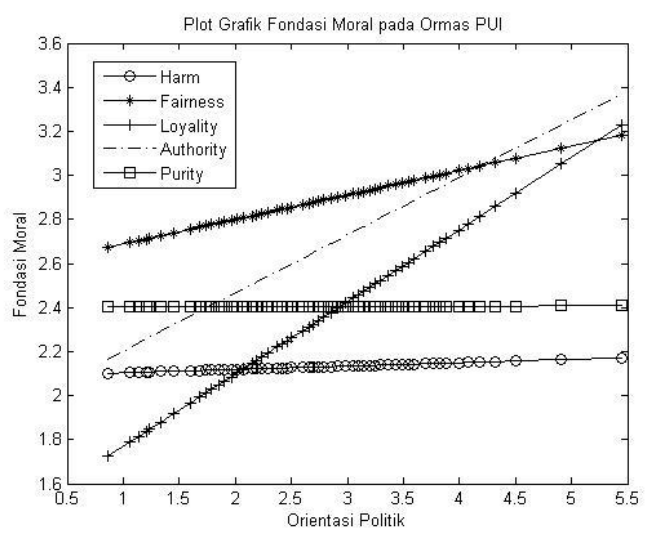

Gambar 5. Hubungan nilai moral dengan orientasi politik islam pada PUI

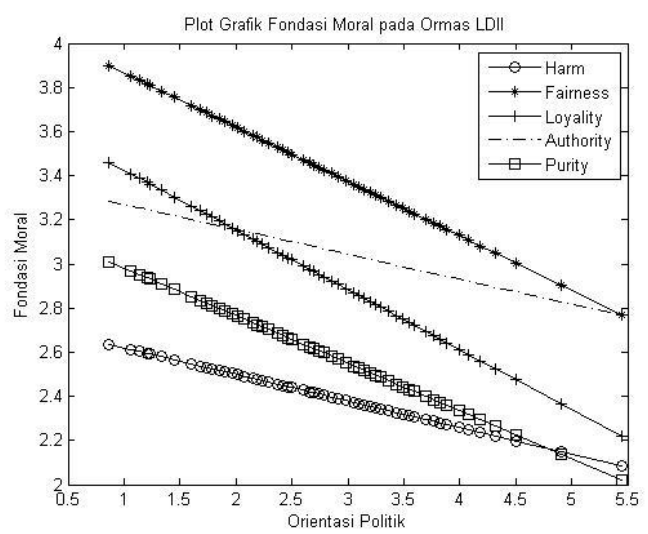

Gambar 6. Hubungan nilai moral dengan orientasi politik islam pada LDII

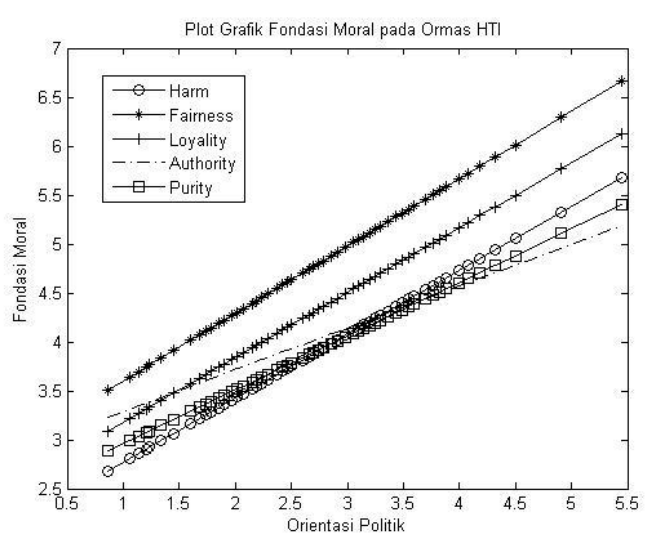

Gambar 7. Hubungan nilai moral dengan orientasi politik islam pada HTI 
Berdasarkan gambar diatas, terdapat pola yang berlainan diantara berbagai kelompok Islam yang ada (NU, Muhammadiyah, Persis, Mathlaul Anwar, PUI, LDII dan HTI) dalam menggunakan nilai moral kaitannya dengan orientasi politik. Perbedaan utama terutama diperlihatkan pada pola di organisai HTI dibandingkan pada organisasi lainnya.

\section{Perbandingan Orientasi Politik Islam pada Kelompok Islam}

Perbandingan ini dilakukan untuk mengetahui orientasi politik Islam pada kelompok Islam yang ada di Indonesia berdasarkan sejauhmana skor dari orientasi politik.

Individu-individu yang berafiliasi pada kelompok Islam dapat dikategorikan dalam orientasi baik inklusif maupun ekslusif. Dengan demikian, berbagai kelompok Islam, baik NU, Muhammadiyah, Persis, Mathlaul Anwar, PUI, LDII dan HTI dapat dibedakan sejauhmana orientasi politiknya, mengarah pada inklusifitas atau ekslusifitas. Lebih lengkap perbandingan orientasi politik Islam pada berbagai kelompok Islam dapat dilihat pada gambar 8 .

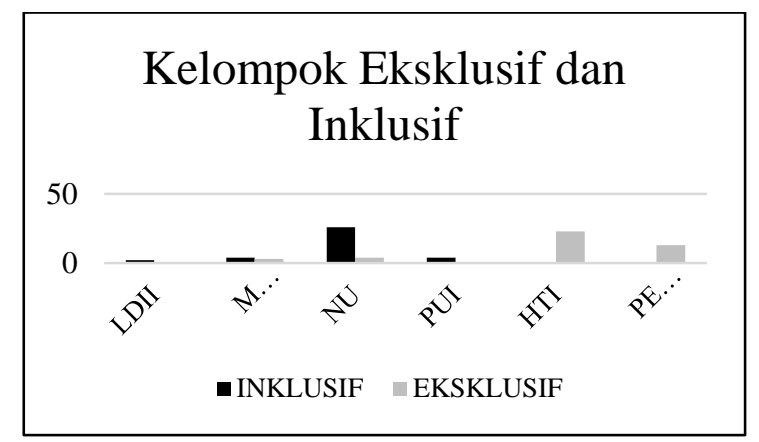

Gambar 8. Perbandingan orientasi politik islam pada kelompok islam

Gambar 8 menunjukkan perbandingan orientasi politik Islam pada berbagai kelompok Islam. Kelompok Islam ini bisa dibedakan dalam orientasi politiknya sepanjang kategori inklusif-ekslusif. Orientasi politik Islam yang paling inklusif dimiliki Nahdlatul Ulama (NU) sedangkan orientasi politik Islam yang paling ekslusif dimiliki Hizbut Tahrir Indonesia (HTI) diikuti dengan Persatuan Islam (Persis). Selebihnya orientasi politik Islam pada kelompok Muhammadiyah, Mathlaul Anwar, PUI, dan LDII menyebar di antara orientasi Islam ekslusif dan inklusif.

\section{Diskusi}

Hasil penelitian menunjukkan bahwa nilai moral bisa berhubungan dengan orientasi politik Islam individu. Berdasarkan kategorisasi orientasi politik Islam ekslusif-inklusif ditemukan perbedaan di antara kelompok Islam yang menjadi sampel penelitian ini. Kelompok Islam dapat terbagi dalam dua kategori besar. Kelompok dengan orientasi politik inklusif yakni NU, Muhammadiyah, Mathlaul Anwar, PUI, dan LDII. Sedangkan kelompok dengan orientasi politik eksklusif, yakni Persis dan HTI. NU adalah kelompok Islam yang memiliki orientasi politik yang paling inklusif, sementara HTI sebagai kelompok Islam yang memiliki orientasi politik yang paling ekslusif, diikuti oleh Persis. Selama ini kelompok muslim NU dikenal sebagai kelompok yang dengan mudah mengadopsi dan menerima ide dan pemikiran dari luar konsep Islam. Tradisi lokal dan konsep modern dari Barat diterima oleh kelompok ini sehingga NU sampai saat ini dikenal sebagai kelompok yang progresif dalam perubahan. Kemunculan kelompok "Islam Liberal" dari kalangan NU sesungguhnya membuktikan inklusifitas dari kelompok muslim ini. Dalam perjalanan sejarah bangsa, NU dikenal sangat kompromis dalam menerima perbedaan terutama pada saat menerima Pancasila sebagai asas tunggal dan dasar negara. Hal ini memberi arti adanya keterbukaan dalam menerima pendapat atau pemikiran lain (Haidar, 1998). NU cenderung memaknakan secara substansial sumber ajaran Alquran dan Hadits. Kelompok ini juga menggunakan pendekatan fikih/ushul fikih dalam mengambil keputusan berkait dengan perubahan sosial yang terjadi di 
masyarakat. Nilai Pancasila diterima terkait bahwa nilai Pancasila tidak bertentangan dengan Islam meskipun bukan murni bersumber dari Alquran dan Hadits.

Di sisi lain kelompok muslim Persis dan HTI keduanya dikenal sebagai kelompok memegang teguh teologi Islam "murni" sehingga terlihat dalam orientasi politiknya yang eksklusif. HTI saat ini dikenal sebagai kelompok Islam yang memiliki ide-ide politik yang berbeda dengan umumnya organisasi keagamaan yang ada di Indonesia. Ide politiknya adalah untuk menegakkan kekhalifahan sebagai wujud mendirikan negara Islam. Ide politik ini adalah hasil pemaknaan secara tekstual Alquran dan Hadits di mana dalam politik tidak bisa dipisahkan dari Islam.

Penjelasan di atas diperkuat dengan temuan penelitian di mana ada pola yang saling bertolak antara NU dan HTI sehubungan dengan hubungan nilai moral terhadap orientasi politik Islam. Pada NU, yang dikenal sebagai kelompok yang menerapkan ajaran secara substansialis, nilai moralitas yang tinggi dibarengi dengan nilai moral kemurnian yang rendah akan membuat orientasi politik semakin inklusif, sementara HTI, sebagai perwakilan kelompok Islam politik, nilai moralitas yang tinggi dibarengi dengan nilai moral kemurnian yang tinggi akan membuat orientasi politik semakin ekslusif. Pola yang berkebalikan ini memperlihatkan pentingnya nilai moral kemurnian. Pada kedua pola kelompok Islam tersebut terlihat nilai kemurnian yang sangat berbeda. Nilai moral kemurnian pada kelompok HTI sangat tinggi sementara pada NU dalam kategori menengah. Nilai moral kemurnian yang berlawanan dengan orientasi politik inklusif seperti yang dipaparkan dalam bab hasil penelitian ini memberikan bukti bagi penjelasan mengenai arah orientasi politik organisasi kemasyarakatan Islam di Indonesia yang selama ini teramati dalam kehidupan politik di Indonesia.
Beberapa hal yang perlu menjadi catatan untuk penelitian lebih lanjut. Pertama, dalam jumlah subjek masih perlu diperluas termasuk dalam hal representatif mengenai usia subjek. Penelitian ini banyak didominasi pada usia 20-30 tahunan. Kedua, representatif dari jumlah subjek dari kelompok muslim kurang lengkap sehingga hanya dapat menyajikan tujuh kelompok muslim besar di Indonesia (NU, Muhammadiyah, Persis, Mathlaul Anwar, PUI, LDII dan HTI). Ketiga, Penjelasan yang diperoleh akan lebih komprehensif jika melibatkan juga kelompok muslim non mainstream, seperti Persatuan Islam Tionghoa Indonesia (PITI), Persatuan Tarbiyah Islamiyah (Perti), dan Harakah Sunniyah Untuk Masyarakat Islami (Hasmi), dll. Keempat, konteks orientasi politik Islam sehingga kurang bisa berlaku luas untuk konteks di luar isu politik Islam.

Pengukuran orientasi politik dalam kategorisasi ekslusif dan inklusif dapat membedakan orientasi politik Islam di Indonesia. Temuan ini sesungguhnya memperkuat penelitian sebelumnya (Kossowska \& Van Hiel, 2003) yang menunjukkan bahwa orientasi/ideologi politik akan berbeda berdasarkan konsep negara; dalam hal ini dominansi masyarakat yang ada pada negara tersebut, konteks budaya yang ada serta isu politik yang berkembang di negara tersebut. Pada negara Polandia yang dimaksud posisi konservatif; dianggap tradisionalis dan status quo, adalah komunisme. Sementara di Flanders yang dimaksudkan konservatif adalah kapitalisme. Dengan demikian menjadi sangat tepat menggunakan kategorisasi ekslusif-inklusif dalam konteks negara Indonesia.

Berdasarkan kategorisasi orientasi politik Islam ekslusif-inklusif ditemukan perbedaan diantara kelompok Islam yang menjadi sampel penelitian ini. Kelompok Islam dapat terbagi dalam dua kategori besar. Kelompok dengan orientasi politik inklusif yakni NU, Muhammadiyah, Mathlaul Anwar, PUI, dan LDII dan 
kelompok dengan orientasi politik eksklusif, yakni Persis dan HTI.

NU adalah kelompok Islam yang memiliki orientasi politik yang paling inklusif, sementara HTI sebagai kelompok Islam yang memiliki orientasi politik yang paling ekslusif, diikuti oleh Persis. Selama ini kelompok muslim NU dikenal sebagai kelompok yang dengan mudah mengadopsi dan menerima ide dan pemikiran dari luar konsep Islam. Tradisi lokal dan konsep modern dari Barat diterima oleh kelompok ini sehingga NU sampai saat ini dikenal sebagai kelompok yang progresif dalam perubahan. Kemunculan kelompok "Islam Liberal" dari kalangan NU sesungguhnya membuktikan inklusifitas dari kelompok muslim ini. Dalam perjalanan sejarah bangsa, NU dikenal sangat kompromis dalam menerima perbedaan terutama pada saat menerima Pancasila sebagai asas tunggal dan dasar negara. Hal ini memberi arti adanya keterbukaan dalam menerima pendapat atau pemikiran lain (Haidar, 1998). NU cenderung memaknakan secara substansial sumber ajaran Alquran dan Hadits. Kelompok ini juga menggunakan pendekatan fikih/ushul fikih dalam mengambil keputusan berkait dengan perubahan sosial yang terjadi di masyarakat. Nilai Pancasila diterima terkait bahwa nilai Pancasila tidak bertentangan dengan Islam meskipun bukan murni bersumber dari Alquran dan Hadits.

Di sisi lain kelompok muslim Persis dan HTI keduanya dikenal sebagai kelompok memegang teguh teologi Islam "murni" sehingga terlihat dalam orientasi politiknya yang eksklusif. HTI saat ini dikenal sebagai kelompok Islam yang memiliki ide-ide politik yang berbeda dengan umumnya organisasi keagaaman yang ada di Indonesia. Ide politiknya adalah untuk menegakkan kekhalifahan sebagai wujud mendirikan negara Islam. Ide politik ini adalah hasil pemaknaan secara tekstual Alquran dan Hadits dimana dalam politik tidak bisa dipisahkan dari Islam.
Hasil penelitian menunjukkan bahwa nilai moral bisa memprediksi dan menentukan arah orientasi politik Islam individu. Dalam hal ini melalui nilai moral kesucian maka nilai moral kepedulian, keadilan, kesetiaan, dan hormat pada otoritas bisa memprediksi orientasi politik Islam. Arah orientasi politik terutama sangat ditentukan oleh sejauhmana nilai moral kesucian. Temuan ini sangat berbeda dari penelitian sebelumnya (Kim, dkk, 2012), dimana semua nilai moral bisa secara langsung memengaruhi orientasi politik. Namun demikian, hal ini menjadi hal sangat mungkin terjadi dikarenakan perbedaan konteks budaya.

Begitu pun sejauhmana dominasi nilai moral ini dalam menentukan orientasi politik sesungguhnya sangat tergantung konteks budaya. Penelitian sebelumnya (Graham, dkk., 2011; Kim, dkk., 2012) memperlihatkan hal tersebut. Dalam konteks Indonesia yang dikenal sebagai negara yang religius maka nilai moral kesucian muncul sebagai penentu dalam arah orientasi politik masyarakat muslim Indonesia. Hal ini menjadi temuan baru dalam penelitian lintas kultural kaitan antara nilai moral dengan orientasi politik.

Penelitian ini menegaskan pola masyarakat Indonesia yang religius, dimana seluruh nilai moral senantiasa dihubungkan dan ditentukan oleh nilai moral kesucian. Nilai moral kesucian ini berkaitan dengan kemurnian, spiritualitas dan mengontrol hasrat. Nilai moral ini didasarkan pada prinsip etika ketuhanan (Haidth dkk., 2009). Graham dkk. (2011), menyebutkan adanya tiga unsur dari etika kesucian, yaitu kesopanan (decency), kejijikan (disgusting), dan aturan tuhan (god rules). Pemaknaan aturan Tuhan ini dipahami sejauhmana penghargaan terhadap otoritas dan tradisi keagamaan. Ini berarti merujuk pada sejauhmana individu memahami, menghayati dan menginterpretasikan ajaran dan tradisi keagamaan yang dianutnya. Dalam hal ini adanya perbedaan pemahaman dalam ajaran agama khususnya 
mengenai pengaturan kekuasaaan dan kemasyarakatan (politik) menjadi inti dari nilai moral kesucian ini.

Unsur kesucian/kemurnian bisa dibedakan dari sejauhmana kemurnian ajaran dalam Islam diinterpretasikan. Ada sekelompok muslim yang meyakini bahwa Islam yang murni adalah yang menerapkan ajaran sebagaimana jaman nabi Muhammad SAW dan para sahabat terdahulu. Oleh karenanya unsur lain baik itu berasal dari budaya lokal ataupun dari luar (Barat) tidaklah diterima. Islam sudah memiliki tata aturan yang lengkap di dalamnya termasuk dalam urusan tata negara (politik) sehingga menjadi hal yang mutlak untuk menolak demokrasi, dan unsur lainnya. Sementara di sisi lain ada sekelompok muslim yang menilai bahwa kemurnian bukan berarti menolak secara mutlak unsur dari luar Islam. Sepanjang prinsip-prinsip dalam Islam, yakni keadilan, musyawarah, dll tidak dilanggar kemurniannya maka tidaklah salah menerima unsur selain Islam.

Bahwa penerapan nilai kesucian secara ketat mencerminkan individu yang hanya ingin menerima unsur Islam secara total dan ini cenderung mengarah pada fundamentalis. Adapun individu yang memegang nilai moral kesucian secara fleksibel mencerminkan individu yang cenderung mengarah pada sikap yang toleran, terbuka terhadap unsur selain Islam selama tidak melanggar kesucian prinsip Islam. Dalam kontek politik Indonesia, ada dua kelompok yang secara murni memegang segala aturan atau ketentuan Tuhan sebagaimana dalam Alquran dan Hadits; dipahami secara tekstual dan pelaksanaannya yang ketat. Arah pandangan ini ingin mewujudkan negara Islam dimana label negara Islam ini dilihat dari sejauhmana syariat Islam diterapkan dalam negara tersebut. Ini sering disebut sebagai Islam politik (Effendy, 2011; Maarif, 1987). Ada juga yang melihat ketentuan Tuhan (syariat Islam) tidak lebih dari sejumlah aturan yang berisi prinsipprinsip dasar yang sesuai dengan konteks ruang dan waktu, sehingga kemungkinan ada perubahan dan penyelarasan agar dapat diakomodasi dan diterapkan dengan mempertimbangkan kemaslahatan individu dan masyarakat. Sumber ajaran dipahami secara substansialis, memerhatikan bagaimana landasan historis-filosofis dari ayat Alquran atau hadits muncul. Pandangan ini lebih menekankan pada nilai-nilai keadilan, persamaan, musyawarah yang tidak bertentangan dengan prinsip Islam.

Hal di atas diperkuat dengan temuan penelitian dimana ada pola yang saling bertolak antara NU dan HTI sehubungan dengan pengaruh nilai moral terhadap orientasi politik Islam. Pada NU, nilai moralitas yang tinggi dibarengi dengan nilai moral kesucian yang tinggi akan membuat orientasi politik semakin ekslusif, sementara HTI nilai moralitas yang tinggi dibarengi dengan nilai moral kesucian yang tinggi akan membuat orientasi politik semakin ekslusif. Pola yang berkebalikan ini memperlihatkan pentingnya nilai moral kesucian. Pada kedua pola kelompok Islam tersebut terlihat nilai kesucian yang sangat berbeda. Nilai moral kesucian pada kelompok HTI sangat tinggi sementara pada NU dalam kategori menengah. Ini menunjukkan bahwa nilai moral kesucian yang berlawanan dengan orientasi politik memberikan bukti arah orientasi politik.

Hasil penelitian sebelumnya mengenai nilai moralitas yang memprediksi orientasi politik ditemukan perbedaan-perbedaan. Salah satunya dengan adanya kemungkinan hubungan yang berkebalikan antara nilai molar dan orientasi politik. Bahwa orientasi politiklah yang kemudian memengaruhi dan memprediksi nilai-nilai moral dari individu. Hal ini perlu dipertimbangkan dalam penelitian selanjutnya mengenai masalah ini. 


\section{Simpulan}

Kelompok Islam yang memiliki orientasi politik inklusif adalah NU, Mathlaul Anwar, Muhammadiyah, PUI, dan LDII. Sementara Persis dan HTI memiliki orientasi politik yang ekslusif. Kedua kelompok yang memiliki orientasi politik yang berbeda ini memiliki skor nilai moral kemurnian yang berbeda dari kelompok lainnya. Skor nilai moral kemurnian pada kelompok ekslusif lebih tinggi dibandingkan kelompok inklusif.

Setiap kelompok muslim Indonesia memperlihatkan pola yang berbeda dalam nilai moral yang memprediksi orientasi politik Islam. Setiap kelompok memiliki variasi dan dominasi yang berbeda dalam menggunakan nilai moral sehubungan dengan orientasi politiknya.

\section{Daftar Pustaka}

Ali, A. A. (2012). Ideologi gerakan pascareformasi: Gerakan-gerakan sosialpolitik dalam tinjauan ideologi. LP3ES.

Claessens, S., Fischer, K., Chaudhuri, A., Sibley, C., \& Atkinson, Q. (2019). The dual evolutionary foundations of political ideology. PsyArxiv. https://doi.org/10.31234/osf.io/6u95j

Boy, P. (2009). Para pembela Islam: Pertarungan konservatif dan progresif di tubuh Muhammadiyah. Granata Publishing.

Chumaidy, C. H. A. (2006). Etika politik \& esensi demokrasi. Pustaka Indonesia Satu.

Duckitt, J., \& Sibley, C. G. (2010). Personality, ideology, prejudice, and politics: A dual-process motivational model. Journal of Personality, 78(6), 1861-1894.

https://doi.org/10.1111/j.14676494.2010.00672.x

Effendy, B. (2011). Islam dan negara: Transformasi pemikiran dan praktik politik Islam di Indonesia. Democracy Project.
Feldman, S. (2003). Values, ideology, and the structure of political attitudes. In D. O. Sears, L. Huddy, \& R. Jervis (Eds.), Oxford handbook of political psychology (p. 477-508). Oxford University Press.

Graham, J., Haidt, J., Nosek, B.A. (2009). Liberals and conservatives rely on different sets of moral foundations. Personality and Social Psychology Review, 96(5), 1029-1046.

Graham, J., Nosek, B. A., Haidt, J., Iyer, R., Koleva, S., \& Ditto, P. H. (2011). Mapping the moral domain. Journal of Personality and Social Psychology, 101(2), 366-385.

Graham, J., Haidt, J., Koleva, S., Motyl, M., Iyer, R., Wojcik, S.P., \& Ditto, P.H. (2012). Moral foundations theory: The pragmatic validity of moral pluralism. Advances in Experimental Social Psychology, 47, 55-130.

Greenberg, J. \& Jonas, E. (2003). Psychological motives and political orientation-The left, the right, and the rigid: Comment on Jost et al. (2003). Psychological Bulletin, 129(3), 376382.

Haidar, M.A. (1998). Nahdlatul Ulama dan Islam di Indonesia: Pendekatan fikih dalam politik. Gramedia.

Haidt, J., Graham, J., \& Joseph, C. (2009). Above and below left-right: Ideological narratives and moral foundations. Psychological Inquiry, 20, 110-119.

Halstead, J.M. (2007). Islamic values: A distinctive framework for moral education? Journal of Moral Education, 36(3), 283-296.

Hatemi, P. K., Crabtree, C., \& Smith, K. B. (2019). Ideology justifies morality: Political beliefs predict moral foundations. American Journal of Political Science, 63(4), 788-806.

Ji, Chang-Ho., Ibrahim, Y. \& Kim, Soo Dong. (2009). Islamic personal religion and moral reasoning in social justice 
and equality: The evidence from Indonesian college students. The International Journal for Psychology Religion, 19, 259-274.

Jost, J. T., Kruglanski, A. W., \& Sulloway. (2003). Political conservatism as motivated social cognition. Psychological Bulletin, 129, 339-375.

Karandikar, S., Kapoor, H., Fernandes, S., \& Jonason, P. K. (2019). Predicting moral decision-making with dark personalities and moral values. Personality and Individual Differences, 140, 70-75. https://doi.org/10.1016/j.paid.2018.03. 048

Kim, K. R., Kang, J., \& Yun, S. (2012). Moral intuitions and political orientation: Similarities and differences between Korea and the United States. Psychological Reports, 111(1), 173-185.

Kim, K.R \& Kang, J. (2013). Liberalconservative self-identification in Korea: a cross-cultural explanation. Korean Soc Sci J, 40, 113-120.

Kossowska, M., \& Van Hiel, A. (2003). The relationship between need for closure and conservative beliefs in Western and Eastern Europe. Political Psychology, 24, 501-518.

Maarif, A.S. (1987). Islam dan masalah kenegaraan: Studi tentang percaturan dalam konstituante. LP3ES.

Medin, D., Ross, N.O., \& Cox, D. (2006). Culture and resource conflict: Why meanings matter. Russell Sage Foundation.

Mujiburrahman. (2014). "Islam Murni” vs "Islam Progresif" di Muhammadiyah: Melihat Wajah Islam Reformis di Indonesia. Dalam Van Bruinessen (Eds.), Conservative turn: Islam Indonesia dalam ancaman fundamentalisme (hal. 157-208). Bandung: Mizan.

Qomar, M. (2012). Fajar baru Islam Indonesia: Kajian komprehensif atas arah sejarah dan dinamika intelektual Islam Nusantara. Bandung: Mizan.

Primaldi, A. \& Takwin, B. (2016). Instrumen pengukuran putusan moral untuk orang Indonesia. (Sedang diproses untuk publikasi).

Rehman, S. S., \& Askari, H. (2010). How Islamic are Islamic countries? Global Economy Journal, 10(2), 1-37.

Schwartz, S. H., Caprara, G. V., \& Vecchione, M. (2010). Basic personal values, core personal values, and voting: A longitudinal analysis. Political Psychology, 31(3), 421-452.

van Bruinessen, M. (2014). Mukadimah: Perkembangan kontemporer Islam Indonesia dan "Conservative Turn" awal abad ke-21. Dalam Van Bruinessen (Eds.), Conservative turn: Islam Indonesia dalam ancaman fundamentalisme (h. 24-49). Mizan.

van Prooijen, J., \& Krouwel, A. (2019). Psychological features of extreme political ideologies. Current Directions in Psychological Science, 28(2). 159163.

https://doi.org/10.1177/096372141881 7755

Voelkel, J. G., \& Brandt, M. J. (2018). The effect of ideological identification on the endorsement of moral values depends on the target group. Personality and Social Psychology Bulletin, 45(6), 851-863. https://doi.org/10.1177/014616721879 8822

Wijaya, T. (2009). Analisis data penelitian menggunakan SPSS. Yogyakarta: Universitas Atmajaya.

Winter, D. G. (2003). Personality and political behavior. In D. O. Sears, L. Huddy, \& R. Jervis (Eds.), Handbook of political psychology (h. 110-145). Oxford University Press. 